\title{
Inventory of ferns and lycophytes within forest fragments of Araucaria in southern Brazil
}

\author{
Ivanete Teresinha Mallmann ${ }^{1 *}$, Vinícius Leão da Silva ${ }^{1} \mathbb{D}^{\mathbb{D}}$ \& Jairo Lizandro Schmitt ${ }^{1}(\mathbb{0}$ \\ ${ }^{1}$ Universidade FEEVALE - Campus II, Instituto de Ciências da Saúde, Laboratório de Botânica, Programa de \\ Pós Graduação em Qualidade Ambiental, Novo Hamburgo, RS, Brasil \\ *Corresponding author: Ivanete Teresinha Mallmann, e-mail: ivamallmann@terra.com.br
}

MALLMANN, I.T., SILVA, V.L., SCHMITT, J.L. Inventory of ferns and lycophytes within forest fragments of Araucaria in southern Brazil. Biota Neotropica. 18(4): e20170348. http://dx.doi.org/10.1590/1676-0611BN-2017-0348

\begin{abstract}
The Araucaria Forest is a unique plant formation, practically restricted to the Atlantic Forest biome, in the South and Southeast of Brazil. It is immensely fragmented and its area is reduced to a minimum fraction, from 13 to $2 \%$ of the original area, due to intense anthropic exploitation. Our study evaluated the richness and floristic composition of ferns and lycophytes within three Araucaria forest fragments, in Rio Grande do Sul, Brazil. For the floristic inventory, a parcel of 1 ha $(100 \times 100 \mathrm{~m})$ was demarcated inside three fragments, which were classified by size: large (246 ha - H1LF), medium (57 ha - H2MF) and small (5.2 ha - H3SF). Occurring species life forms and preferential substrates up to 4 meters above ground were recorded. In total, 55 species were catalogued, only two of which were lycophytes, distributed in 32 genera and 17 families. Considering the area of fragments, the recorded species richness has decreased, presenting greater numbers in H1LF (48), followed by H2MF (33), and H3SF (29). In the three sites, terrestrial substrate and the hemicryptophyte species life form predominated. We observed that one hectare of a larger forest fragment presented $65 \%$ more species than that of a smaller one, considering that the smaller fragment total area represents only $2 \%$ of the larger forest's area. On the other hand, one hectare of the smaller fragment contributed $17 \%$ to fern and lycophyte species conservation occurring in Brazilian Araucaria Forests, and 8\% to the state of Rio Grande do Sul's total richness. The diverse heterogeneity and species composition grants floristic identity to each of the studied forest interiors. Our results highlight the need to include the botanical parameters here analyzed in management, conservation degree evaluation, and maintenance of Araucaria Forests plant biodiversity.

Keywords: Mixed Ombrophilous Forest, fragmentation, seedless vascular plants, floristic inventory.
\end{abstract}

\section{Inventário de samambaias e licófitas em interiores de fragmentos de Floresta com Araucária no Sul do Brasil}

Resumo: A Floresta com Araucária é uma formação vegetal única do planeta com ocorrência praticamente restrita ao bioma Mata Atlântica, no Sul e Sudeste brasileiro. Ela está imensamente fragmentada e sua área reduzida a uma fração mínima, de 2 a 13\% da cobertura original, devido à intensa exploração antrópica. Nosso estudo avaliou a riqueza e a composição florística de samambaias e licófitas, no interior de três fragmentos de Floresta com Araucária, no Rio Grande do Sul, Brasil. Para o inventário florístico, foi demarcada uma parcela de 1 ha (100x100m) no interior de três fragmentos, os quais, por sua vez, foram classificados por tamanho: grande (246 ha - H1LF), médio (57 ha - H2MF) e pequeno (5,2 ha - H3SF). Foram registradas a forma de vida e o substrato preferencial das espécies ocorrentes até $4 \mathrm{~m}$ de altura do solo. Ao total, foram inventariadas 55 espécies, das quais apenas duas licófitas, distribuídas em 32 gêneros e 17 famílias. Considerando a área dos fragmentos, a riqueza registrada de espécies foi decrescente, sendo maior no H1LF (48), seguida do H2MF (33) e H3SF (29). Nos três sítios predominaram as espécies no substrato terrícola e a forma de vida hemicriptófita. Observamos que um hectare do fragmento florestal grande apresenta $65 \%$ mais espécies que o de um pequeno, considerando que a área total do fragmento menor representa apenas $2 \%$ da área do maior. Por outro lado, o hectare do fragmento pequeno contribui para a conservação de $17 \%$ das espécies de samambaias e licófitas ocorrentes em Floresta com Araucária no Brasil e 8\% da riqueza total para o Estado do Rio Grande do Sul. A heterogeneidade na riqueza e na composição de espécies confere identidade florística própria a cada um dos interiores florestais estudados. Os nossos resultados destacam a necessidade da inclusão dos parâmetros botânicos analisados no manejo, na avaliação do grau de conservação e na manutenção biodiversidade vegetal da Floresta com Araucária.

Palavras-chave: Floresta Ombrófila Mista, fragmentação, plantas vasculares sem sementes, inventário florístico. 


\section{Introduction}

Araucaria Forest (AF) or Mixed Ombrophilous Forest (MOF) is a unique vegetation formation on the planet (Koch 2002), practically restricted to the Atlantic Forest biome in South and Southeast Brazil (Backes, 2009). It is estimated that, originally, this forest covered an extension of 200 thousand $\mathrm{km}^{2}$, immensely fragmented due to the intense exploration occurred from the 19th century onwards. Araucaria Forest territory is reduced to a minimal fraction (2 to $13 \%$ of the original area) of which only $3 \%$ are within conservation units (Ribeiro et al. 2009). Araucaria angustifolia (Bertol.) Kuntze is an arboreal species that stands out in the upper stratum and confers typical and unique characteristics to the forest structure composition (Kozera et al. 2006). Another typical species of MOF is the Dicksonia sellowiana Hook., which is a tree fern found more frequently in areas with high araucaria density (Fernandes 2000). In addition to the fact that they harbor characteristic species and unique biological attributes (Oliveira-Filho et al. 2013), Araucaria Forest remaining areas have been considered an environmental conservation priority (Duran \& Peixe 2008).

Habitat fragmentation is a global process and possibly the most intense man-made change to the environment, especially in tropical regions (Harris 1984). The Atlantic Forest biome presents $83 \%$ of the remaining fragments with less than 50 ha total area (Ribeiro et al. 2009), expressively disturbed, isolated, poorly protected (Viana 1995), and poorly studied (Safford 2007). The impacts are a consequence of this biome's use and occupation history, which houses the largest Brazilian industrial cities and centers (MMA 2000). According to Rands e Whitney (2010), fragmentation of forests is threatening the sustainability of their interior environment, along with their inherent ecological attributes and functions. Consequently, maintaining many forest ecological values requires the maintenance of forest interiors.

In Brazil, the most abundant and endemic species in the Atlantic Forest biome, in the South and Southeastern regions, especially in the Dense and Mixed Ombrophilous Forests (Sehnem 1979), are seedless vascular plants (Smith et al. 2006). Considering ferns and lycophytes, these regions are among the most diverse and endemic on the planet (Brummitt et al. 2016). A total of 1,313 are described for Brazil, being 1,143 ferns species and 170 lycophytes, out of which $38 \%$ are endemic (Prado \& Sylvestre 2016). These two groups are Brazilian flora's most threatened plants (Martinelli \& Moraes 2013).

Ferns and lycophytes have developed a number of adaptations throughout their evolution in relation to the substrate (Windisch 1992), and this biological diversity demonstrates these plants' ability to inhabit different environments (Senna \& Waechter 1997). Among ferns and lycophytes floristic inventories in Araucaria Forests in Rio Grande do Sul, we highlight the study by Silva \& Schmitt (2015), who verified a significantly greater richness in the interior environment. Blume et al. (2010) collected a total of 42 ferns and lycophytes samples in a unit of 1 ha inside the forest interior. These are one of the most important forest components (Costa 2004), representing up to $80 \%$ of the herbaceous stratum vegetative cover in Seasonal Forests (Inácio \& Jarenkow 2008).

The objectives of the present study were: (1) to evaluate ferns and lycophytes richness and floristic composition within three Araucaria Forest fragments in Rio Grande do Sul; (2) to analyze life forms and preferential substrates of the species, and (3) to compare, floristically, these sites with other inventories of the same sample size.

\section{Material and Methods}

\section{Study Area}

The study was conducted in Aparados da Serra National Park (ASNP) in Cambará do Sul (2907'58.53'S and 5006'18.89'W, 1024m altitude), Rio Grande do Sul, Brazil. The Park, created in 1959, has an area of $13,141.05 \mathrm{ha}$, and is bordered by the Serra Geral National Park both to the south and north, and the two units are managed by Ministry of the Environment's Chico Mendes Institute for Biodiversity Conservation (ICMBio). According to the Köppen-Geiger classification, regional climate is $\mathrm{Cfb}$, that is, humid continental $(\mathrm{C})$, with rains distributed during all months of the year (f), with average temperature of the warmest month being inferior to $22^{\circ} \mathrm{C}$ (b) (Peel et al. 2007). The soil of the region is shallow to deep, classified as Cambissolo Húmico Alumínico, associated with a litolical neosol. Because an area of high rainfall and low temperatures, organic matter accumulation is favored (Streck et al. 2008).

Three plots of 1 ha $(100 \times 100 \mathrm{~m})$ were demarcated for the inventory, within three Araucaria Forest fragments of different sizes, being the matrix habitat composed of natural fields. The large fragment (LF) has a total area of 246 ha $\left(29^{\circ} 08^{\prime} 04.09^{\prime \prime} \mathrm{S}\right.$ and $\left.50^{\circ} 07^{\prime} 06.86^{\prime \prime} \mathrm{W}\right)$, the medium-sized fragment (MF) has a total area of 57 ha $\left(29^{\circ} 07^{\prime} 10.43^{\prime \prime} \mathrm{S}\right.$ and $50^{\circ} 06^{\prime} 54.53^{\prime \prime} \mathrm{W}$ ), and the small fragment (SF) has 5.2 ha $\left(29^{\circ} 07^{\prime} 58.70^{\prime \prime} \mathrm{S}\right.$ and $\left.50^{\circ} 06^{\prime} 17.89^{\prime \prime} \mathrm{W}\right)$, referred to as H1LF, H2MF and H3SF, respectively (Figure 1).

\section{Collection and Identification of Botanical Material}

During one year, periodic expeditions to the sample units were carried out in order to perform the floristic inventory. This survey was made on the hectare demarcated through observation of ferns and lycophytes occurring in the herbaceous and epiphytic strata (up to $4 \mathrm{~m}$ in height). Fertile specimens were collected according to techniques proposed by Windisch (1992). The samples were deposited at Herbarium Anchieta (PACA), São Leopoldo, Rio Grande do Sul. The taxonomic identification was made through specialized bibliography, comparisons with material determined in herbarium and by specialist consultation. Species classification in families and botanical genera adopted the system suggested by Schuettpelz et al. (2016). The plants were evaluated for life forms following Raunkiaer (1934), and adaptations of Mueller-Dombois \& Ellenberg (1974), and Senna \& Waechter (1997). As to their preferential substrate, they were classified as terrestrial (species that occur exclusively in the soil), corticicolous (species that occur in tree bark) or hemicorticicolous (species that establish themselves in the soil and grow in the phorophyte) as proposed by Mynssen (2000), modified by Athayde Filho \& Windisch (2006).

\section{Statistical analysis and comparison with other studies}

For the floristic composition similarity analysis of the three sites studied, a binary matrix was constructed, representing the species' presence or absence in each sample unit. A grouping analysis was carried out using the Unweighted Pair-Group Method with Arithmetic Averages (UPGMA) and the Sorensen index (BRAY-CURTIS) with a cophenetic correlation of 0,99 (Gotelli \& Ellison 2001), in the Paleontological Statistical Program Statistics - PAST (Hammer et al. 2001) version 3.0. Five other sites with the same sample area were 


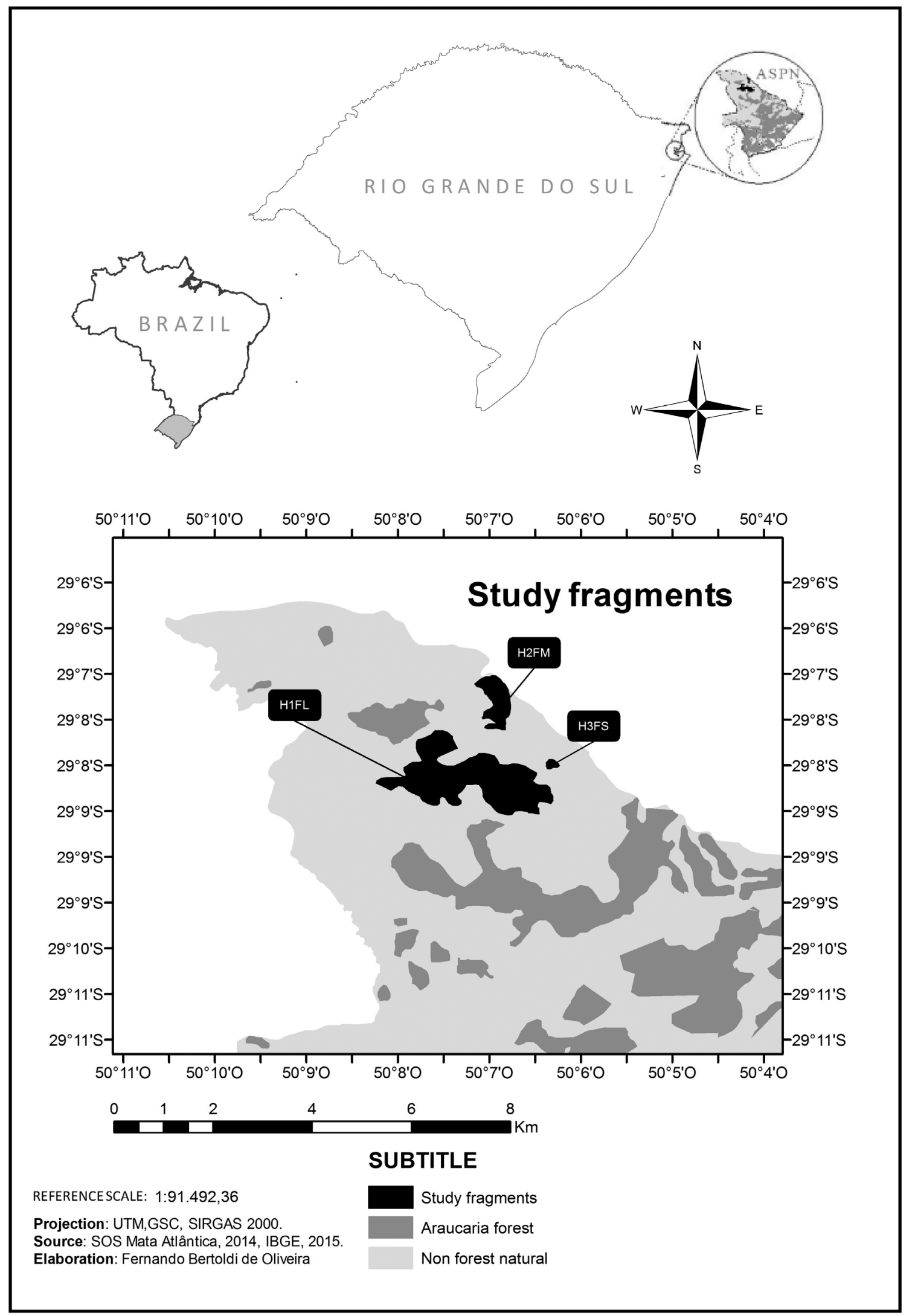

Figure 1. Location of the Araucaria forest fragments showing H1LF, H2MF and H3SF sites in the Aparados da Serra National Park (ASNP), State of Rio Grande do Sul, Brazil. 
included for comparison purposes: Blume et al. (2010), in Araucaria Forest; Burmeister \& Schmitt (2016) and Athayde-Filho \& Windisch (2006), both on the coastal plain, in Rio Grande do Sul; the inventory of Dittrich et al. (2005), carried out in Dense Ombrophilous Forest (DOF), in Paraná, also in southern Brazil; and the Poulsen \& Nielsen (1995) study, in an Ecuadorian Tropical Rainforest.

\section{Results}

The total floristic survey indicated the occurrence of 55 species, of which 53 are ferns and two lycophytes, represented 38 genera and 17 families (Table 1). Among the sites studied, H1LF had the highest number of species (48). H2MF had similar richness to H3SF, with 33 and 29 species, respectively. The three fragments registered 20 species in common, and in H1LF, 14 species were exclusive (not found in the other two sites), whereas in H3SF and H2MF there were only one and four exclusive species, respectively.

The most represented families in the three fragments were Polypodiaceae (10 species), followed by Hymenophyllaceae (seven), Aspleniaceae (seven) and Thelypteridaceae (six). Together these four families accounted for $56.36 \%$ of the total surveyed species. Seven families were represented by only one species (Table 1). The richest genera were Asplenium (seven species), Amauropelta (five species), Hymenophyllum, Pecluma and Pleopeltis (three species).

Regarding the type of preferential substrate, considering the three fragments, the terrestrial rate predominated with 29 species registered (approximately 52.72\%), followed by corticicolous, 25 species (45.45\%), and one hemicorticicolous species (1.81\%). Separately, the terrestrial species (H1LF: $54.16 \%$, H2MF: $57.57 \%$ and H3SF: $51.72 \%$ ) also predominated.

Among the 24 hemicryptophyte species, 16 presented rosulate growth and eight reptant growth. From the corticicolous species, 21 were reptant and three rosulate. The two phanerophyte species were of rosulate growth, as were the two camephyte species.

The analysis of floristic similarity (Table 2) evidenced the formation of two groups (A and B) ( Fig. 2). The demarcated hectare's floristic composition in the Ecuadorian rain forest presented the lowest similarity, forming an independent group (A) and sharing only Vittaria lineata (L.) $\mathrm{Sm}$. with the other studies. Group B integrated all inventories made in Brazil and shared Pleopeltis hirsutissima (Raddi) de la Sota and $V$. lineata. The Ca subgroup was composed by all the inventories made in Araucaria Forests, and the present study's three sites formed subgroup (Db), which presented the highest similarity sharing 20 species. The survey by Blume et al. (2010), also in Araucaria Forest (Da), shared 21 species with H1LF, whereas 18 species were shared with H2MF and H3SF. Both inventoried hectares in the coastal plain of Rio Grande do Sul remained in the same subgroup $(\mathrm{Cb})$.

\section{Discussion}

Ferns and lycophytes richness demonstrated the importance of studying AF interiors for spore-producing vascular plant biodiversity conservation. Our results corresponded to $40 \%$ of the species cited for Araucaria Forests in Rio Grande do Sul, as well as $14.62 \%$ of the total species recorded in this state. The number of fern and lycophyte families sampled represented half of the 34 occurrences in Rio Grande do Sul (Flora do Brasil 2020). The fact that lycophytes are less representative when compared to ferns is related to this group's low richness, which currently represents less than $1 \%$ of all vascular plants (Smith et al. 2006).

$\mathrm{H} 1 \mathrm{LF}$ richness is $45 \%$ greater than that of $\mathrm{H} 2 \mathrm{MF}$, and the forest area in which this second hectare is inserted corresponds to $23 \%$ of the first's area. This comparison indicates that fragments with greater forest interior areas have a tendency to present higher seedless vascular plant species richness. Other ferns and lycophytes studies show negative impacts on the composition, richness, diversity and abundance of these species in the fragmentation process and habitat loss (Paciencia \& Prado 2005, Barros et al. 2006, Silva \& Schmitt 2015). In general, ferns and lycophytes are known to inhabit wet and shaded sites in a variety of microenvironments (Kessler et al. 2011). Favorable environmental conditions may depend on both forest interior area size and natural environment preservation degree, since fragmentation tends to homogenize this type of ecosystem in its most impacted areas (Fahrig 2003; Cagnolo et al. 2006; Lôbo et al. 2011).

Comparing the present study's results with other surveys performed in a sample area of 1ha, it is evident that H1LF presented similar richness to that observed by Poulsen \& Nielsen (1995) $(\mathrm{S}=50)$ in tropical forests in Ecuador. It was also close to the richness verified by Blume et al. (2010) $(\mathrm{S}=42)$ in AF, Rio Grande do Sul. Only in the Dittrich et al. (2005) study in Paraná's Dense Ombrophilous Forest, species richness was higher $(S=81)$ than that recorded in this study's sites, due to the high number of epiphytes (49 species), corroborating with Waechter (1998), who states that the richness of epiphytic flora decreases in more southern latitudes.

In $\mathrm{H} 3 \mathrm{SF}$, richness $(\mathrm{S}=29$ ) was similar to that recorded in Rio Grande do Sul's coastal region by Burmeister \& Schmitt (2016) ( $S=28)$, and by Athayde-Filho \& Windisch (2006) $(\mathrm{S}=26)$ in fragments with a total area similar to the ones presented here: 6 ha and 4 ha, respectively. These three sites shared only four species (Cyathea atrovirens, Pleopeltis hirsutissima, Serpocaulon catharinae (Langsd. and Fisch.) A.R.Sm. (Fig. 3) and Vittaria lineata). However, H3SF shared seven species with the other surveys. The three other sites are more floristically heterogeneous among themselves when compared to the three hectares inventoried in this study, which in turn shared 13 more species. In general, the fragment's spatial proximity increases the likelihood of propagule movements between them (Guevara \& Laborde, 1993); therefore, the present study's three hectares were more floristically homogeneous out of all the compared sites.

$\mathrm{AF}$ and coastal sites that have formed distinct subgroups have different climatic conditions. In Campos de Cima da Serra, where our AF hectares were located, the average monthly temperature is lower than the average in the coastal plain (Peel et al. 2007). Thus, it is evident that, besides forest type, climate was also important for floristic differentiation. It is important to evaluate that in spite of these vegetative and climatic differences between mountain and coastal plain, some species can occupy different niches due to their functional characteristics, which makes them generalist, plastic, of wider distribution, and, therefore, resilient to the fragmentation processes. Morphological properties such as small surface and coriaceous leaf texture, thick rhizome with water reserve, and nutrients 
Floristic Inventory

Table 1. Fern and lycophyte species distribution in the three Araucaria Forest sites of Rio Grande do Sul, grouped by family, with respective life form and preferential substrate.

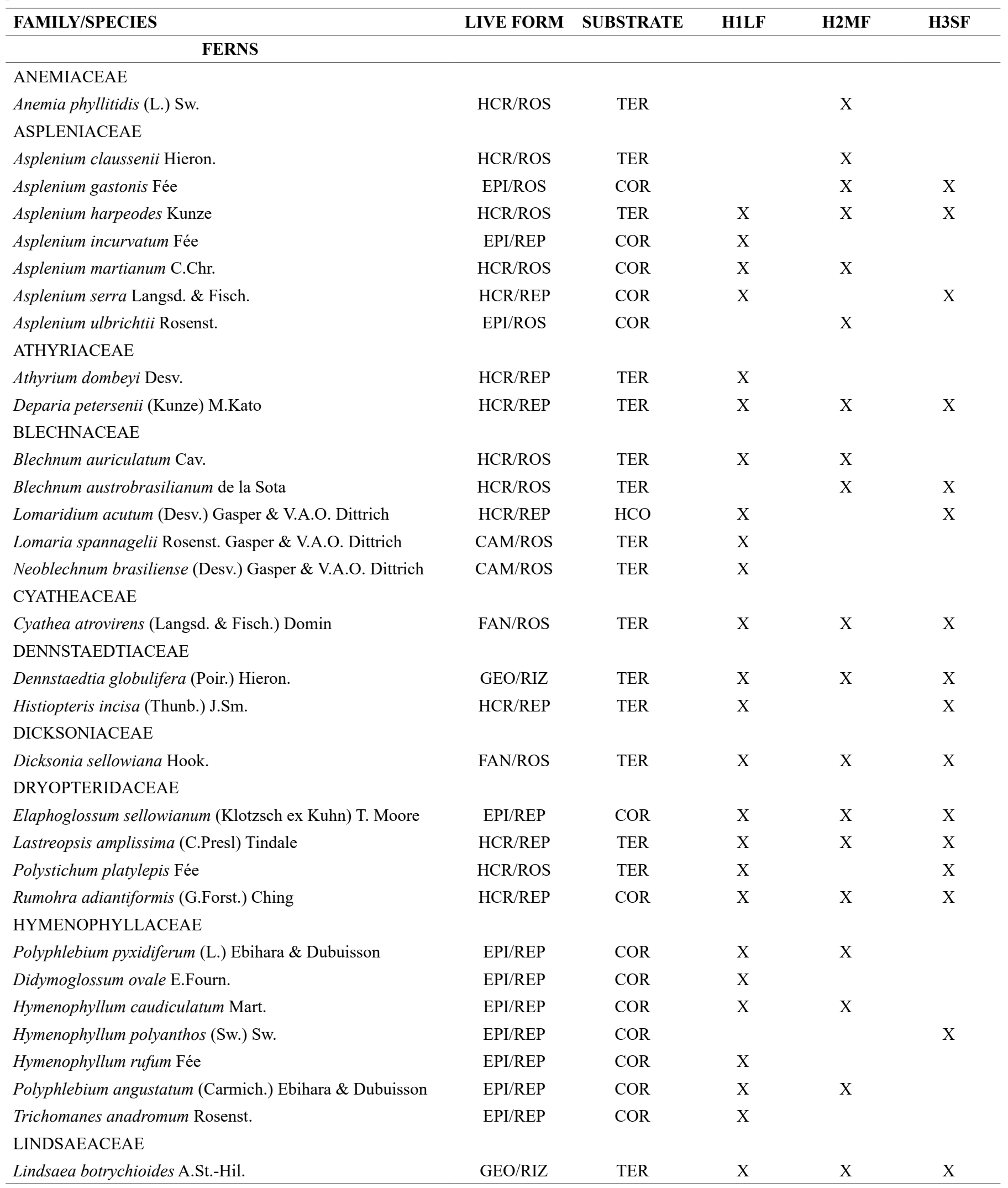


Continuation Table 1.

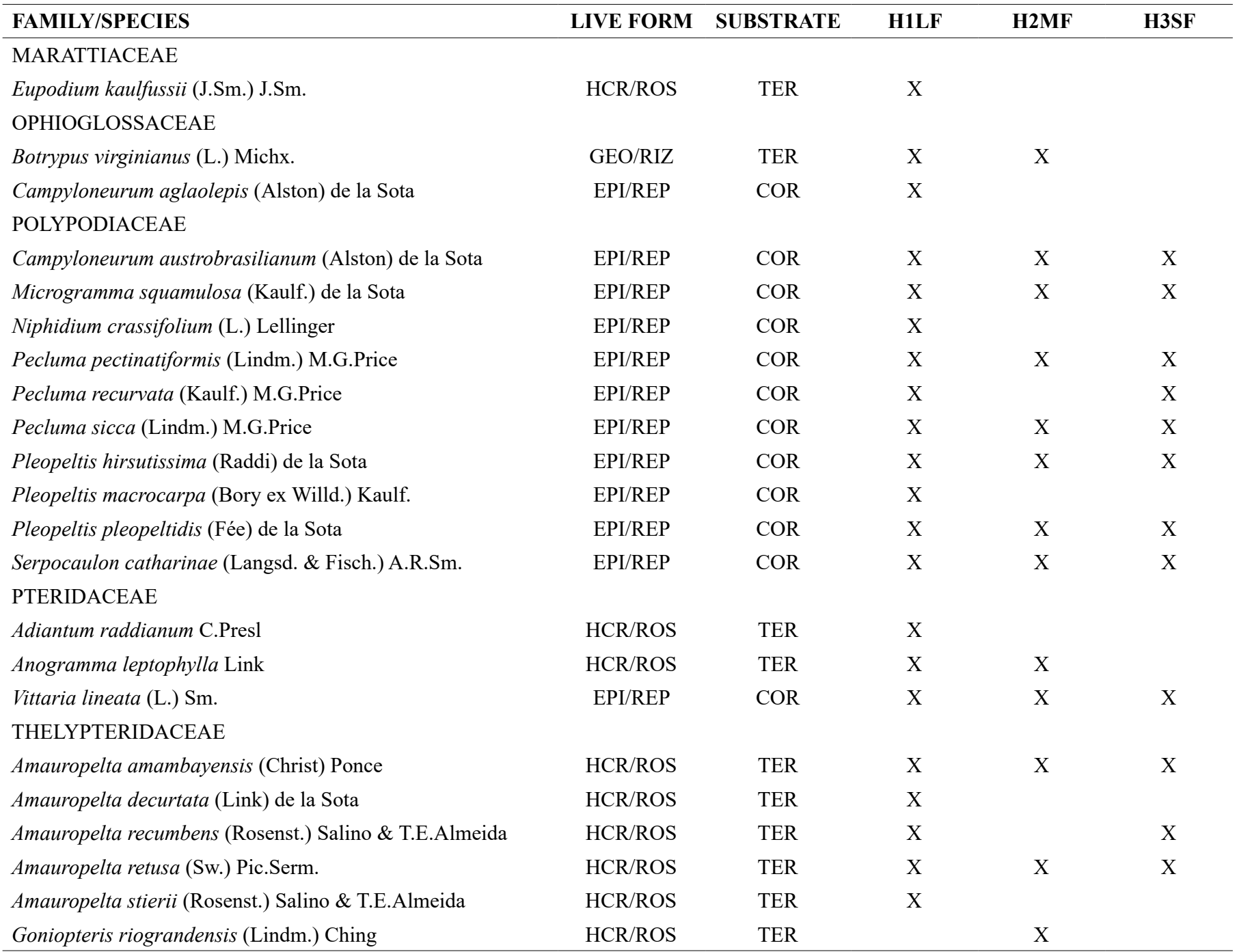

\section{LYCOPHYTES}

\section{LYCOPODIACEAE}

Phlegmariurus quadrifariatus (Bory) B.Øllg.

EPI/ROS COR X

SELAGINELLACEAE

\begin{tabular}{lccccc} 
Selaginella muscosa Spring & HCR/REP & TER & X & X & X \\
\hline TOTAL SPECIES & 55 & & 48 & 33
\end{tabular}

Life forms: HCR/ROS: rosulate/hemicryptophyte, EPI/ROS: rosulate/epiphyte, EPI/REP: reptant/epiphyte; HCR/REP: reptant/hemicryptophyte; CAM/ROS: rosulate/camephyte; FAN/ROS: rosulate/phanerophyte; GEO/RIZ: rhizomatous/geophyte. Preferential substrate: TER= terrestrial; $\mathrm{COR}=$ corticicolous; $\mathrm{HCO}=$ hemicorticicolous. Scientific names were confirmed using the List of Species of Flora of Brazil (Flora do Brasil 2020).

Table 2. Ferns and lycophytes inventories carried out in a sample area of one hectare in different forest types

\begin{tabular}{llcl}
\hline Acronyms & Forest type & Number of species & Reference \\
\hline (AF-RS6) & Araucaria Forest & 48 & Present study (H1LF) \\
(AF-RS8) & Araucaria Forest & 33 & Present study (H2MF) \\
(AF-RS7) & Araucaria Forest & 29 & Present study (H3SF) \\
(AF-RS5) & Araucaria Forest & 42 & Blume et al. (2010) \\
(SF-RS4) & Swamp Forest & 28 & Burmeister \& Schmitt (2016) \\
(RF-RS3) & Rain Forest & 26 & Athayde-Filho \& Windisch (2006) \\
(RF-PR2) & Rain Forest - Paraná & 81 & Dittrich et al. (2005) \\
(RF-EC1) & Rain Forest - Ecuador & 50 & Poulsen \& Nielsen (1995) \\
\hline
\end{tabular}


Floristic Inventory

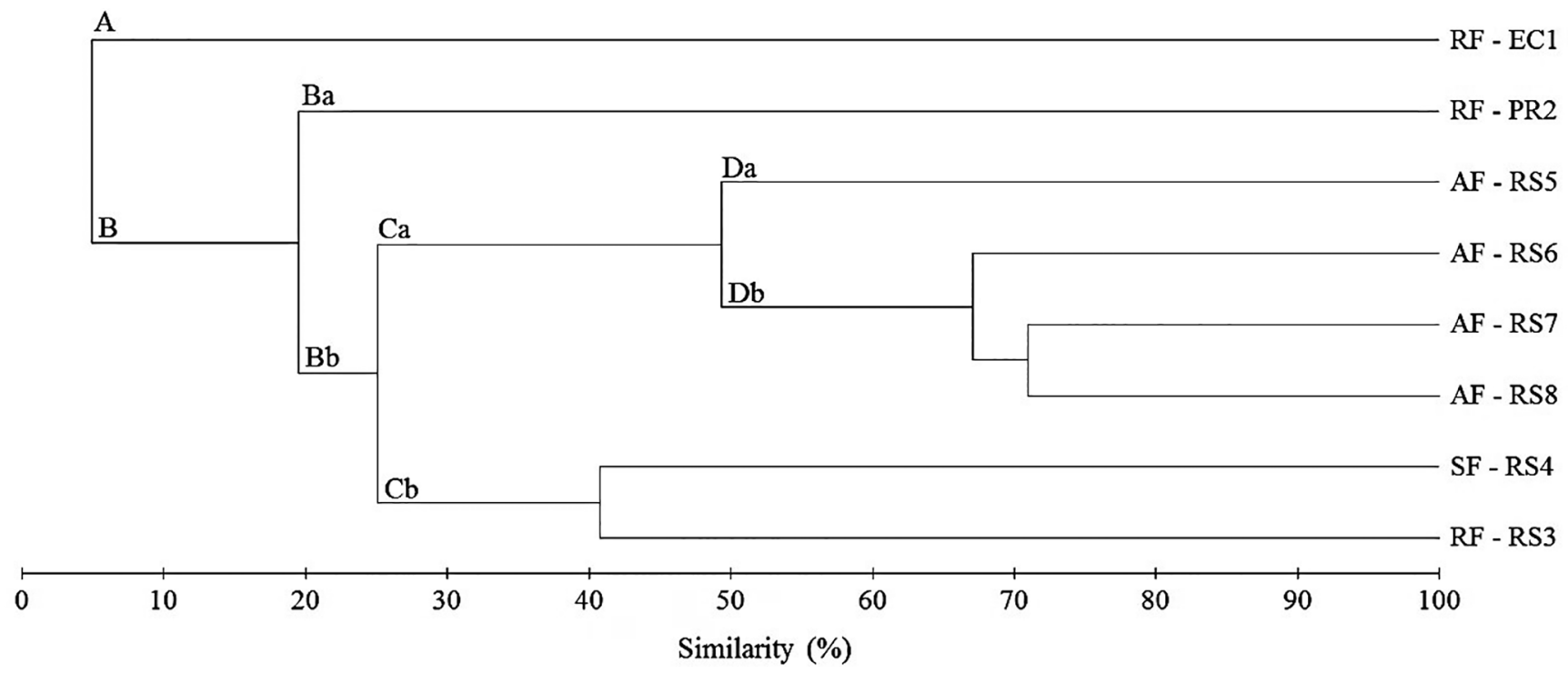

Figure 2. Dendrogram of floristic similarity between eight ferns and lycophytes inventories carried out in a sample area of one forest hectare. Araucaria Forest (AF), Rain Forest (RF), Swamp Forest (SF), Ecuador (EC), Paraná (PR), Rio Grande do Sul (RS). ${ }^{1}$ Poulsen e Nielsen (1995), ${ }^{2}$ Dittrich et al (2005), ${ }^{5}$ Blume et al. (2010), ${ }^{6,78}$ Present study, ${ }^{4}$ Burmeister e Schmitt (2016) and ${ }^{3}$ Athayde-Filho e Windisch (2006). Cophenetic correlation: 0.99.

in Vittaria lineata, Serpocaulon catharinae and Pleopeltis hirsutissima (Ranal 1993), may have favored the establishment of these species in those sites. Studies indicate that $P$. hirsutissima is a generalist species and $S$. catharinae occurs both in forest interior and in altered areas (Prado et al. 2010). The same is true for C. atrovirens, which was found in a variety of places, from locations conditioned to full sunlight to places with moderate shade, in forest areas, ravines and trenches along roads and highways (Lehn \& Leuchtenberger 2008).

Analysis of fern and lycophyte communities' composition and their ecological aspects expresses the environmental quality of the studied fragments and the disturbance variation levels of these sites. Ferns and lycophytes are considered important indicators of environmental quality because they are directly affected by alterations (habitat loss and fragmentation) and are considered important ecological indicators because they are susceptible to environmental changes (Silva et al. 2018; Silva \& Schmitt 2015; Mallmann et al. 2016). During field work, we observed that Dicksonia sellowiana officially threatened with extinction according to Ordinance No. 443 of December 17, 2014 (MMA 2014), presented only young individuals in H2MF, whereas in H1LF and $\mathrm{H} 3 \mathrm{SF}$ they presented as adults. Considering that a $5 \mathrm{~m}$ adult individual is approximately 90 years old, since the slow growth of that species (5.6 $\mathrm{cm}$ year- ${ }^{1}$ ), according to estimation by Schmitt et al. (2009), the highest degree of conservation and succession is evident in the two last fragments. Corroborating with field observations, previous documented records indicate that only in 2001 the H2MF fragment was effectively incorporated into the Park Unit.

The removal of $D$. sellowiana individuals, one of the most typical AF species, not only uncharacterizes this forest formation (Fernandes 2000), but also reduces microhabitats availability for species that use their caudice as a preferential substrate, as is the case of Polyphlebium angustatum (Carmich.) Ebihara and Dubuisson and Trichomanes anadromum Rosenst. (Schmitt et al. 2005), recorded in the H1LF. In the absence of $D$. sellowiana, P. angustataum only occurred in H2MF because it used Cyathea atrovirens, another species of arborescent fern, as mechanical support.
H2MF also recorded the lowest epiphytic richness (42.42\%) among the three forest interiors sampled, which refers to the shortest time period in which the fragment was legally protected. Epiphytic plants are considered to be excellent environmental quality indicators due to their physiological and nutritional characteristics (Bataghin et al. 2010), affecting the local preservation degree (Johansson 1989, Wolf 2005). In the comparison, including two sites, the largest number of species was shared between H2MF and H1LF.

H3SF recorded only one Hymenophyllaceae species, while H1LF presented six of the seven species inventoried for this family. Hymenophyllaceae comprises a group of $10 \%$ of fern species with green spores, which, due to their chlorophyll content, have limited viability of only a few weeks (Lloyd \& Klekowski 1970), and are strongly dependent on microenvironments with constant humidity, making them more vulnerable to forest disturbances. However, because they have small spores, their chances of establishing themselves in favorable microhabitats increases, making them locally abundant and forming large colonies (Mehltreter 2010), as observed in H1LF.

Similarly to the present study, hemicryptophyte species prevalence was also observed by Blume et al. (2010) in fern and lycophyte communities inventoried in one AF hectare. Hemicryptophytes have a widespread occurrence in different environments (Schmitt \& Goetz 2010) and can survive well under unfavorable climatic conditions since their buds are located at ground level and protected by scales or previous season's dry leaves (Caiafa \& Silva 2005), which favors the this life form's establishment in low temperature environments (Raunkiaer 1934). However, this observation is not standard in inventories of seedless vascular plants, so much so that Poulsen e Nielsen (1995) recorded 50\% epiphytes. Dittrich et al. (2005) found that this life form predominated in rain forests, totaling $60 \%$ of the richness. This last vegetation type is considered the most diverse in epiphytes in South-Brazilian forests, followed by AF (Roderjan et al. 2002).

Plant communities and species responses to fragmentation are known to vary in response to several factors (Laurance 1990, Ouborg 1993) and that forest area alone is an incomplete indicator of the forests' 

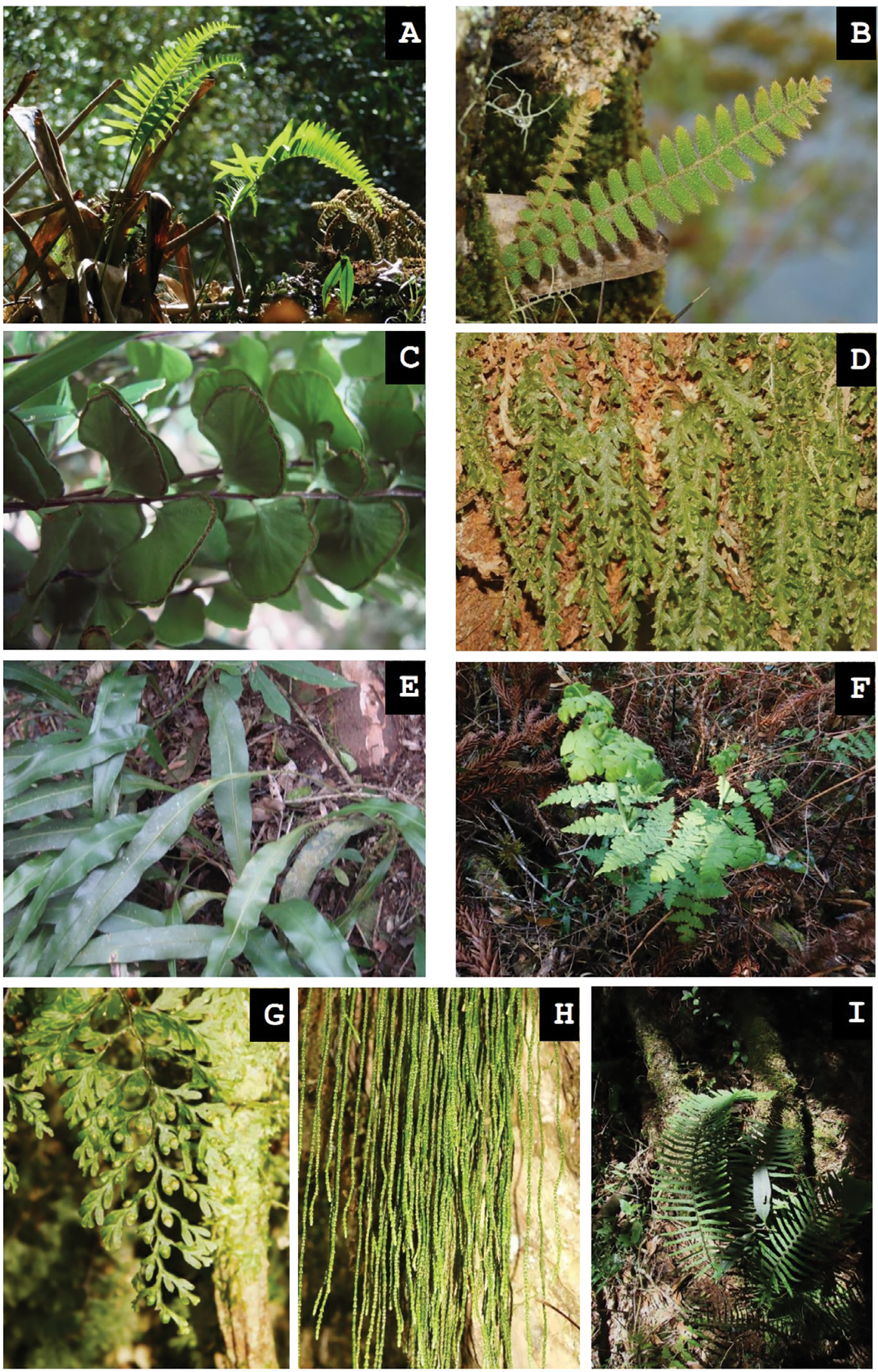

Figure 3. Fern and lycophyte species occurrences in the three Araucaria Forest sites of Rio Grande do Sul: A) Serpocaulon catharinae, B) Pleopeltis hirsutissima, C) Lindsaea botrychioides, D) Trichomanes anadromum, E) Elaphoglossum sellowianum, F) Histiopteris incisa, G) Hymenophyllum polyanthos, H) Phlegmariurus quadrifariatus, I) Pecluma recurvata. 
ability to maintain ecological services (Chazdon 2008). Long-term experiments are needed to elucidate and predict long-term fragmentation effects (Haddad et al. 2015).

Based on the floristic survey, our study showed that H1LF was the site that presented the most favorable conditions for fern and lycophyte communities' development. We observed that a large forest fragment supports $65 \%$ more species than a small one, considering that the smaller fragment area represents only $2 \%$ of the LF area. Although its area is reduced, the SF presents a greater degree of conservation and succession than the MF. It also presents the less exposed soil, due to the greater coverage of the herbaceous stratum. This remnant represents a stepping stone in the displacement and the dispersion of species by the landscape, reducing the isolation between the larger fragments. Even a small fragment can contribute to fern and lycophyte conservation, since it sustains $17 \%$ of fern and lycophyte richness for this type of forest in Brazil, and $8 \%$ of total richness in Rio Grande do Sul, including one threatened species (Dicksonia sellowiana). Ferns and lycophytes species richness at local scale is determined by habitat heterogeneity, since even if there is no restriction for dispersion; the spores need a favorable microhabitat for germination (Mehltreter 2010). As in the present study, AF fragments floristic heterogeneity was also observed in surveys conducted in the State of São Paulo by Polisel et al. (2014), who analyzed the subsurface community of four fragments, and found significant differences in richness and diversity.

The set of the three forest fragments should be considered a priority for preservation and conservation. Richness and heterogeneity in species composition that confer their own floristic characteristics to each of the forest interiors studied, along with the critical conservation status of $\mathrm{AF}$, confirm that sites such as these are particularly important for plant biodiversity maintenance. The floristic data obtained support the determination of the zoning of the Park area by the managers of this Conservation Unit. In addition, they support the importance and necessity of including the botanical parameters analyzed in the management and evaluation of the Araucaria Forest conservation degree.

\section{Acknowledgements}

The authors are grateful to the Coordenação de Aperfeiçoamento de Pessoal de Nível Superior (CAPES) for the grants awarded to the first two authors, to Universidade Feevale for the available infrastructure, and to colleagues of the Botany Laboratory for their support in field and laboratory works.

\section{Author Contributions}

Ivanete Teresinha Mallmann: Substantial contribution in the concept and design of the study; Contribution to data collection; Contribution to data analysis and interpretation; Contribution to manuscript preparation.

Vinícius Leão da Silva: Substantial contribution in the concept and design of the study; Contribution to data collection; Contribution to data analysis and interpretation; Contribution to critical revision, adding intelectual content.

Jairo Lizandro Schmitt: Contribution to critical revision, adding intelectual content.

\section{Conflicts of interest}

The authors declare that they have no conflict of interest related to the publication of this manuscript.

\section{References}

ATHAYDE-FILHO, F.P. \& WINDISCH, P.G. 2006. Florística e aspectos ecológicos das pteridófitas em uma Floresta de Restinga no Estado do Rio Grande do Sul, Brasil. Iheringia, Série Botânica. v.61(1-2): 63-71.

BACKES, A. 2009. Distribuição geográfica atual da floresta com araucária: condicionamento climático. In: FONSECA, C. R. ed. Floresta com araucária: ecologia, conservação e desenvolvimento sustentável. Ribeirão Preto, Holos. p. 39-44.

BARROS, I.C.L. et al. 2006. Pteridófitas. p. 148-171. In: TABARELLI, M.; ALMEIDA-CORTZ, J.S.; PÔRTO, K.C. (Eds.). Diversidade Biológica e conservação de Floresta Atlântica ao Norte do Rio São Francisco. Brasília: Ministério do Meio Ambiente.

BATAGHIN, F.A.; BARROS, F. \& PIRES, J.S.R. 2010. Distribuição da comunidade de epífi tas vasculares em sítios sob diferentes graus de perturbação na Floresta Nacional de Ipanema, São Paulo, Brasil. Revista Brasileira de Botânica, 33(3): 501-512.

BLUME, M., FLECK, R., \& SCHMITT, J. L. (2010). Riqueza e composição de filicíneas e licófitas em um hectare de Floresta Ombrófila Mista no Rio Grande do Sul, Brasil. Revista Brasileira de Biociências, v. 8 (4).

BRUMMITT, N. et al. 2016. Taking stock of nature: essential biodiversity. Biological Conservation.

BURMEISTER, E. L. \& SCHMITT, J. L. 2016. Species richness and composition of ferns in a fragment of dense humid forest in Rio Grande do Sul, Brazil. Pesquisas Botânica, v. 69, p. 157.

CAGNOLO, L., M. C. \& VALLADARES, G. 2006. Plant species richness in the Chaco Serrano Woodland from central Argentina: Ecological traits and habitat fragmentation effects. Biological Conservation.

CAIAFA, A. N.; \& SILVA, A. F. 2005. Composição florística e espectro biológico de um Campo de Altitude no Parque Estadual da Serra do Brigadeiro, Minas Gerais - Brasil. Rodriguésia. 56. p. 163-173.

CHAZDON, R. L. 2008. Beyond deforestation: Restoring forests and ecosystem services on degraded lands. Science. v. 320, 1458-1460.

COSTA, F.R.C. 2004. Structure and composition of the ground-herb community in a terra firme Central Amazonian Forest. Acta Amazonica, v. 34:53-59.

DITTRICH, V.A., WAECHTER, J. L. \& SALINO, A. 2005. Species richness of pteridophytes in a montane Atlantic rain forest plot of Southern Brazil Acta Botanica Brasilica. 19: 519-525.

DURAN, M. F. \& PEIXE, B. C. S. 2008. Proposta de um estudo de política pública para conservação e uso da floresta ombrófila mista Cap. 7. In: Gestão de Políticas Públicas no Paraná: Coletânea de Estudos. Organizadores: Blênio César Severo Peixe, Cleise M. de A. Tupich Hilgemberg, Gerson Antonio Melatti, Geysler Rogis Flor Bertolini, Hilka Pelizza Vier Machado. Curitiba: Editora Progressiva, vol. 1, 516 p.

FAHRIG, L. 2003. Effects of habitat fragmentation on biodiversity. Annual Reviews in Ecology. Evolution and Systematics, (34). p. 487-515.

FERNANDES, I. 2000. Taxonomia dos representantes de Dicksoniaceae no Brasil. Pesquisas Botânica, 50. p. 5-26.

FLORA DO BRASIL 2020 em construção. 2016. Jardim Botânico do Rio de Janeiro. Available in: floradobrasil.jbrj.gov.br/ Access in: Jan 16th, 2017.

GOTELLI, N. J. \& COLWELL, R. K. 2001. Quantifying biodiversity: procedures and pitfalls in the measurement and comparison of species richness. Ecology Letters, Boston. v. 4, p. 379-391.

GUEVARA, S. \& LABORDE, J. 1993. Monitoring seed dispersal at isolated standig trees in tropical pastures: consequences for local species availability Vegetatio. 107/108, 319-338. 
HADDAD N. M.; BRUDVIG L. A.; CLOBERT J.; DAVIES K. F.; GONZALEZ A.; HOLT R. D.; LOVEJOY T. E.; SEXTON J. O.; AUSTIN M. P.; COLLINS C. D.; COOK W. M.; DAMSCHEN E. I.; EWERS R. M.; FOSTER B. L.; JENKINS C. N.; KING A. J.; LAURANCE W. F.; LEVEY D. J.; MARGULES C. R.; MELBOURNE B. A.; NICHOLLS A. O.; ORROCK J. L.; SONG D. X.; TOWNSHEND J. R. 2015. Habitat fragmentation and its lasting impact on Earth's ecosystems. Sci Adv 1: e1500052.

HAMMER, Ø. et al. 2001. PAST: Paleontological Statistics Software Package for Education and Data Analysis. Palaeontologia Electronica. v. 4, n. 1, p. 1-9.

HARRIS, L. D. 1984. The fragmented forest: island biogeography theory and the preservation of biotic diversity. University of Chicago press.

INÁCIO, C. D. \& JARENKOW, J. A. 2008. Relações entre a estrutura da sinúsia herbácea terrícola e a cobertura do dossel em floresta estacional no Sul do Brasil. Revista Brasileira de Botânica, 31(1), 41-51.

JOHANSSON, D.R. 1989. Vascular epiphytism in Africa. In: LlETH, H. e WERGER, M. J. (eds.). Tropical rain forest ecosystems, Ecosystems of the world. Amsterdam, v. 14. p. 7-53.

KESSLER, M.; KLUGE, J.; HEMP, A. \& OHLEMÜLLER, R. A. 2011. Global comparative analysis of elevational species richness patterns of ferns. Global Ecol Biogeogr. vol. 20, p. 868-880.

KOCH, Z. \& CORRÊA M. C. 2002. Araucária: a floresta do Brasil Meridional. Curitiba: Olhar Brasileiro, p. 148.

KOZERA, C.; DITTRICH, V.A, O. \& SILVA, S.M. 2006. Fitossocilogia de um componente arbóreo de um fragmento de floresta ombrófila mista montana, Curitiba, Paraná, Brasil. Floresta, Curitiba. v. 36, n. 2, p. 225- 237.

LAURANCE, W. F. 1990. Comparative aspects of five arboreal marsupials to tropical forest fragmentation. J. Mamm, 71: 641-653.

LEHN, C. R. \& LEUCHTENBERGER, C. 2008. Resistência ao fogo em uma população de Cyathea atrovirens (Langsd. and Fisch.) Domin (Cyatheaceae) no Estado do Rio Grande do Sul, Brasil. Biotemas, vol. 21, no. 3, p. 15-21.

LLOYD, R. M. \& KLEKOWSKI, E. J. 1970. Spore germination and viability in Pteridophyta: evolutionary significance of chlorophyllous spores. Biotropica, 2, 129-37.

LÔBO, D. et al. 2011. Forest fragmentation drives Atlantic forest of northeastern Brazil to biotic homogenization. Diversity and Distributions. 17. 287-296.

MALLMANN, I. T.; SILVA, V. L. \& SCHMITT, J. L. 2016. Estrutura comunitária de samambaias em mata ciliar: avaliação em gradiente de antropização. Revista Ambiente \& Água, v. 11, n. 1, p. 110-124, Available in: doi: 10.4136/ ambi-agua.1717.

MARTINELLI G. \& MORAES M. A. 2013. Livro vermelho da flora do Brasil. Rio de Janeiro, Instituto de Pesquisas Jardim Botânico do Rio de Janeiro.

MEHLTRETER, K. 2010. Fern conservation Cap 9 p. 334-. In: MEHLTRETER, K.; WALKER, L.R.; SHARPE, J.M. (Eds.). Fern Ecology. New York: Cambridge University Press.

MINISTÉRIO DO MEIO AMBIENTE (MMA). 2014. Atualização das Listas de Espécies Ameaçadas http://www.mma.gov.br/biodiversidade/especiesameacadas-de extincao/atualizacao-das-listas-de-especies-ameacadas (last access in Mar 13th, 2017).

MMA, MINISTÉRIO DO MEIO AMBIENTE (2000). Avaliações de ações prioritárias para a conservação da biodiversidade da Mata Atlântica e Campos Sulinos. Brasília: MMA, 40p.

MUELLER-DOMBOIS, D. \& ELLENBERG, H. (1974). "Aims and methods of vegetation ecology."

MYNSSEN, C.M. 2000. Pteridófitas da Reserva Rio das Pedras, Mangaratiba, RJ. 170f. Dissertação (Mestrado em Botânica) - Museu Nacional, Universidade Federal do Rio de Janeiro, Rio de Janeiro. 2000.

OLIVEIRA-FILHO, A. T., BUDKE, J. C., JARENKOW, J. A., EISENLOHR, P. V., \& NEVES, D. R. 2013. Delving into the variations in tree species composition and richness across South American subtropical Atlantic and Pampean forests. Journal of Plant Ecology, Oxford, 6: p.1-23.

OUBORG, N. J. 1993. Isolation, population size and extinction: the classical and metapopulation approaches applied to vascular plants along the Dutch Rhine-system. Oikos, 66. 298-308.
PACIENCIA, M. L. B. \& PRADO, J. 2005. Distribuição espacial da assembléia de pteridófitas em uma paisagem fragmentada de Mata Atlântica no sul da Bahia, Brasil. Hoehnea, v. 32, n. 1, p.103-117.

PEEL M. C. FINLAYSON B. L. \& MCMAHON T. A. 2007. Updated world map of the Köppen-Geiger climate classification. Hydrology and Earth System Science, v. 11, n.5, p. 1633-1644.

POLISEL, R. T. et al. 2014. Structure of the understory community in four stretches of Araucaria forest in the state of São Paulo, Brazil. Acta Botanica Brasilica, 28: 86-101.

POULSEN, A. D. \& NIELSEN I. H. 1995. How Many Ferns Are There in One Hectare of Tropical Rain Forest? American Fern Journal, n. 85, p. 29-35.

PRADO, J., HIRAI, R.Y. \& SCHWARTSBURD, P.B. 2010. Criptógamos do Parque Estadual das Fontes do Ipiranga, São Paulo, SP. Pteridophyta: 9. Grammitidaceae e 16. Polypodiaceae. Hoehnea. 37(3): 445-460.

PRADO, J. \& SYLVESTRE, L. 2016. Samambaias e Licófitas in Flora do Brasil 2020 em construção. Jardim Botânico do Rio de Janeiro. Available in: $<$ http://floradobrasil.jbrj.gov.br/reflora/floradobrasil/FB128483>. Access in: Jan 16th, 2017.

RANAL, M. A. 1993. Desenvolvimento de Polypodium hirsutissimum Raddi (Pteridophyta, Polypodiaceae) em condições naturais. Acta Bot. Bras. Feira de Santana, v. 7, n.2, p. 03-15 Available in: <http://www.scielo.br/scielo. php?script=sci_arttextandpid=S0102 33061993000200001 andlng=enandn $\mathrm{rm}=$ iso $>$. Access in: 22th Sep. 2017.

RANDS, S. A. \& WHITNEY, H. M. 2010. Effects of pollinator densitydependent preferences on field margin visitations in the midst of agricultural monocultures: A modelling approach. Ecological Modelling, v. 221, n. 9, p. $1310-1316$

RAUNKIAER, C. 1934.The life forms of plants and statistical plant geography. Oxford: Clarendon Press. $632 \mathrm{p}$

RIBEIRO, M. C., METZGER, J. P., MARTENSEN, A. C., PONZONI, F. J., \& HIROTA, M. M. 2009. The Brazilian Atlantic Forest: How much is left, and how is the remaining forest distributed? Implications for conservation. Biological conservation, 142(6). p. 1141-1153.

RODERJAN, C.V. et al. 2002. As unidades fitogeográficas do Estado do Paraná. Revista Ciência e Ambiente, 24. p. 75-92.

SAFFORD, H. D. 2007. Brazilian Páramos IV. Phytogeography of the campos de altitude. Journal of Biogeography, v. 34, p. 1701-1722.

SCHMITT, J. L., WINDISCH, P. G. \& BUDKE, J. C. 2005. Aspectos florísticos e ecológicos de pteridófitas epifíticas em cáudices de Dicksonia sellowiana Hook. (Pteridophyta, Dicksoniaceae), São Francisco de Paula, RS, Brasil. Pesquisas Botânica, São Leopoldo - RS - Brasil, v. 56, p. 161-172.

SCHMITT, J.L. \& GOETZ, MNB. 2010. Species richness of fern and lycophyte in an urban park in the Rio dos Sinos basin, Southern Brazil. Brazilian Journal of Biology (Impresso) v. 70, p. 1161-1167.

SCHMITT, J. L., SCHNEIDER, P. H. \& WINDISCH, P. G. 2009. Crescimento do cáudice e fenologia de Dicksonia sellowiana Hook. (Dicksoniaceae) no sul do Brasil. Acta Botanica Brasilica, v. 23, p. 282-291.

SCHUETTPELZ, E., SCHNEIDER, H., SMITH, A. R., HOVENKAMP, P., PRADO, J., Rouhan, G. \& SESSA, E. B. 2016. A community-derived classification for extant lycophytes and ferns. Journal of Systematics and Evolution, 54(6), 563-603.

SEHNEM, A. 1979. Semelhanças e diferenças nas formações florestais do Sul do Brasil. Acta Biológica Leopoldensia 1, p. 111-135.

SENNA, R.M. \& WAECHTER, J.L. 1997. Pteridófitas de uma floresta com araucária. Formas biológicas e padrões de distribuição geográfica, Iheringa, $48,41-58$

SILVA, V. L. \& SCHMITT, J.L. 2015. The effects of fragmentation on Araucaria forest: analysis of the fern and lycophyte communities at sites subject to different edge conditions. Acta Botanica Brasilica, v. 29, p. 223-230.

SILVA, V. L., MEHLTRETER, K. V., SCHMITT, J. L. 2018. Ferns as potential ecological indicators of edge effects in two types of Mexican forests. Ecological indicators, v. 93, p. 669-676. 
SMITH, A.R.; PRYER, K.M.; SCHUETTPELZ, E.; KORALL, P.; SCHNEIDER, H. \& WOLF, P.G. 2006. A classification for extant ferns. Taxon,. 55. p. $705-731$.

STRECK, E.V., KÄMPF N., DALMOLIN, R.S.D., KLAMT, E., NASCIMENTO, P.C., SCHNEIDER, P., GIASSON, E. \& PINTO, L.F.S., 2008. Solos do Rio Grande do Sul. Porto Alegre: EMATER/RS. Eds. 2a, pp. 222.

VIANA, V. M. 1995. Conservação da biodiversidade de fragmentos de florestas tropicais em paisagens intensivamente cultivadas. In: Abordagens interdisciplinares para a conservação da biodiversidade e dinâmica do uso da terra no novo mundo. Belo Horizonte/Gainesville: Conservation International do Brasil/Universidade Federal de Minas Gerais/ University of Florida. 135-154.
WAECHTER, J.L. 1998. Epiphytic orchids in eastern subtropical America. Proceedings of the 15th World Orchid Conference. Naturalia Publications, Turriers, pp. 332-341.

WINDISCH, P.G. 1992. Pteridófitas da Região Norte-Ocidental do Estado de São Paulo - Guia para excursões. (Eds. $2^{\mathrm{a}}$ ) Universidade Estadual Paulista Campos de São José do Rio Preto. 110p.

WOLF, J.H.D. 2005. The response of epiphytes to anthropogenic disturbance of pine-oak forests in the highlands of Chiapas, Mexico. Forest Ecology and Management. 212:376-393.

Received: $29 / 08 / 2017$

Revised: $16 / 07 / 2018$

Accepted: 23/07/2018

Published online: 23/08/2018 